\title{
The Contribution of Islamic Educational Institutions to the Change of Social Life of Gayo Plateau People During Covid- 19
}

Musradinur, Faisal Husen Ismail, Sabirin, Arwansyah Kirin, Zaitun Muzana

To Link this Article: http://dx.doi.org/10.6007/IJARBSS/v11-i4/9742

DOI:10.6007/IJARBSS/v11-i4/9742

Received: 21 February 2021, Revised: 23 March 2021, Accepted: 15 April 2021

Published Online: 27 April 2021

In-Text Citation: (Musradinur et al., 2021)

To Cite this Article: Musradinur, Ismail, F. H., Sabirin, Kirin, A., \& Muzana, Z. (2021). The Contribution of Islamic Educational Institutions to the Change of Social Life of Gayo Plateau People During Covid-19. International Journal of Academic Research in Business and Social Sciences, 11(4), 892-900.

Copyright: @ 2021 The Author(s)

Published by Human Resource Management Academic Research Society (www.hrmars.com)

This article is published under the Creative Commons Attribution (CC BY 4.0) license. Anyone may reproduce, distribute, translate and create derivative works of this article (for both commercial and non-commercial purposes), subject to full attribution to the original publication and authors. The full terms of this license may be seen at: http://creativecommons.org/licences/by/4.0/legalcode

Vol. 11, No. 4, 2021, Pg. 892 - 900

Full Terms \& Conditions of access and use can be found at http://hrmars.com/index.php/pages/detail/publication-ethics 


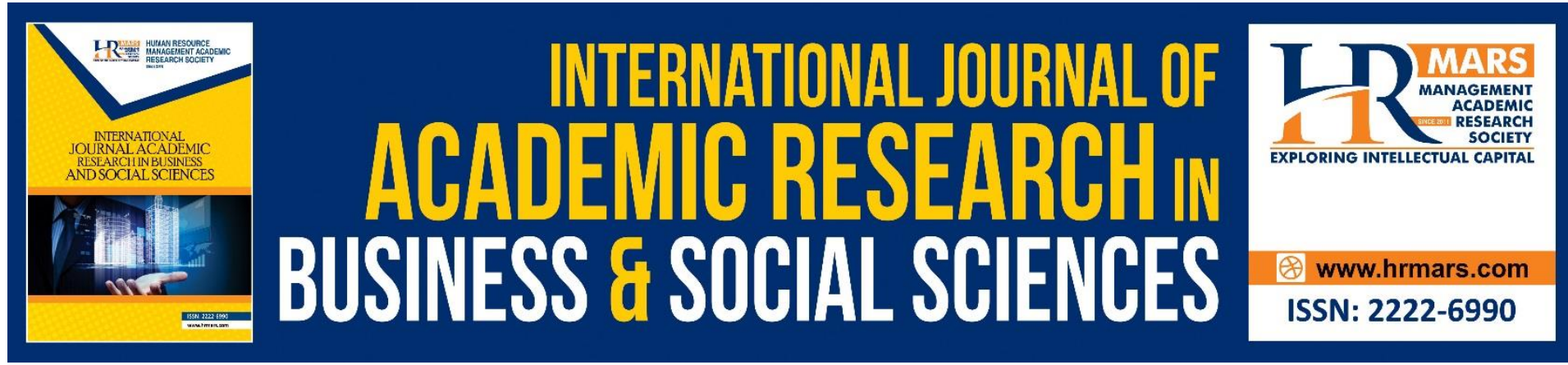

\title{
The Contribution of Islamic Educational Institutions to the Change of Social Life of Gayo Plateau People During Covid-19
}

\author{
Musradinur \\ State Institute of Islamic Religion (IAIN) Takengon, Aceh, Indonesia
}

Faisal Husen Ismail

Universiti Tun Hussein Onn Malaysia, Centre for General Studies and Co-curricular, 86400

Parit Raja, Batu Pahat, Johor, Malaysia

Email: faisalhu@uthm.edu.my

Sabirin

State Islamic University Ar-Raniry, Banda Aceh Indonesia

\section{Arwansyah Kirin}

Universiti Tun Hussein Onn Malaysia, Centre for General Studies and Co-curricular, 86400

Parit Raja, Batu Pahat, Johor, Malaysia

\author{
Zaitun Muzana \\ University College Bestari, Terengganu, Malaysia
}

\begin{abstract}
This study aims to find the contribution of Islamic educational institutions in the framework of character development among Gayo it still conducts the process of distance education high ground communities during the Covid-19 pandemic. We conducted this study with a qualitative approach, which is based on observation of social symptoms and phenomena that occur in the community. We selected case studies as the proper type of study for this study. We try to see and study a symptom of a phenomenon that is clear in an incident in the highlands of Gayo, Aceh Indonesia. The study also found the Takengon State Islamic Institute took progressive measures in the face of covid-19. It still conducts the process of distance education to keep students alive despite the covid-19. Lecturers and students conduct studies to find out the various problems that occur in the community, examine problems, and find solutions to them. Lectures or counseling conducted to educate the public to support strict health protocols. The contribution of Islamic educational institutions to the change in the social life of the Gayo plateau community during the covid-19 period is realized as implementing the Tri Dharma of Higher Education, including Education, Research and
\end{abstract}


Community Service. This study suggests a more in-depth study related to the impact of Covid19 on the humanitarian nature of students during the Covid-19 pandemic.

Keyword: Islamic Educational Institutions, Social life, Gayo, Covid-19.

\section{Introduction}

Education is a system and one-way humans improve the quality of life in every aspect of human life. In the history of humanity, almost no group of people has not used education as an instrument of culture and quality improvement, even though the condition of the society is left behind (Sanaky, 2003). In its development, educational institutions have a tendency to adjust to the socio-cultural changes of the surrounding community, to answer every problem that occurs in the community.

Islamic education is a solution for the rapid development of the times and not accompanied by the development of enough human resources so that the development of the era will affect the community. This phenomenon impacts religious, social life and the development of community education in a direction that should not happen, because of the people who are experiencing rapid lag in time to adjust (Bogmatsera, et.al., 2019).

The current condition cannot be seen that the public has practiced in implementing Islamic education. Education could not make Muslims to practice the teachings of Islam as a whole, the practice of Islam is still symbolic, has not touched the true essence of the practice of Islamic teachings (Benn, et.al., 2011). Perhaps empirically, most have understood the teachings of Islam, but its essence has not. Whereas the academic world has done a lot of exploration to formulate moral and character education to help find solving this problem, which is a problem of society, it is also a matter of the nation that is practical, efficient, effective and effective, so that the practice of Islamic teachings can be practiced in all areas of life, from the lower level to the top level.

Departing from thinking, anxiety and question marks are so great, then academics, those who are engaged in Islamic education, trying to find answers about why these things happen, and with what steps, which can change bad behavior for good, as well as who can play a role in social religion, community education and the suppression of people to realize a civilized society.

To know the common thread that is difficult, academics still try to change behavior by offering alternative problem solving as an effort for scientific donations, through the study of Islamic education organizing which is one of the pillars of Islamic education by researching and analyzing Islamic educational institutions that have functions and very significant benefits of presence in the framework of character development.

Islamic education in the development's era of science and technology today questioned its relevance, if it is associated with its contribution to the formation of character, modern culture that is influenced by the development of science and technology. In this context, education is subject to functional degradation, as education is oriented towards material elements (Karim, 1991). Education is appointed as a social asset that has a special function in preparing the workforce that will meet the demands of the industrialist's world of employment. The suitability of an educational program can be resolved from how far the educational output can contribute in filling the jobs provided by the industrialized world.

Education as one unit of the social system, constrained by various rules and policies that do not allow the birth of a flexible education and able to face the surrounding development. Curriculum revision is difficult to do, although it is realized that the development of society has far exceeded what students get in formal education, while nonformal education has also 
not found its ideal form. Such a long process of education in Islamic educational institutions will foster religious social changes and the development of education in the community so that it will give birth to a society that has broad insights and applies every knowledge that can be to itself, its exit and society.

Today the world community, including Indonesia faces a condition that makes people shocked and afraid of the covid-19 virus that has never been experienced by modern humans today by changing social patterns, this adds to the complexity of problems faced by Muslims, the covid-19 virus spread amid society, not only attacking human health, but the economic sector is inseparable from the ferocity of the covid-19 virus. Many countries in the world do lockdown to make human mobility limited like never.

With sociol-cultural changes that occur in the community in the Gayo Plateau at the time of the covid-19 outbreak, the shift in value in Gayo society occurs in the social field which changes are felt during diversity of society. For example, at the beginning of covid-19 worship activities that have the potential to gather people are limited, mosques are closed, even interactions with other human beings are limited, even educational institutions are closed and it often refers distance learning to as online (Faisal, et.al., 2020). This is something new for Gayo people who have a high social spirit every day. it is required to always change in a better direction, but what is happening in the world including in the Gayo plateau shows that the change is worrying because it is incompatible with the ancestral heritage tradition of the Gayo community which is known for its high social taste, but as the case of covid-19 disappears in the Gayo plateau makes its social society return to normal, but no longer the same as before the covid-19 outbreak.

Therefore, it is interesting to examine the contribution of Islamic educational institutions as the last bastion in maintaining the morality and morals of society to the social changes that occur, or indeed Islamic educational institutions are not present amid changes that occur in society, which Islamic educational institutions control any change that is sunnatullah in a good direction. The purpose of the research is to find out the contribution of Islamic educational institutions to the change in the social life of Gayo plateau people during the covid-19 period. We conducted the research with a qualitative approach, which is based on understanding based on research method and understanding based on method that investigates social symptoms and phenomena that occur in society. We chose case studies as the right type of research to use in the study, which is to see and study a symptom of a phenomenon that is clear in an event (Yin, 1994).

\section{Institute of Islamic Education and Social Change}

Islamic educational institutions are educational institutions that offer the idea of the importance of supporting morality to form a strong community order. With a strong moral building base, of course, this nation can conduct a selection and filter process against all kinds of new cultures that come in as an effect of development, openness, and advancement of information technology that is so remarkable today. Islamic educational institutions are the strongest moral bulwark that the Indonesian nation has in the face of the current attacks of globalization, technology, and information. This fact is undeniable to anyone. These Islamic educational institutions do not grow at once, but through the process, as happens in other institutions. There are three models of Islamic educational institutions in Indonesia that have contributed to forming students who are educated and moral namely pesantren, madrasah, and Islamic universities. (1) Pesantren: There are many terms that are often used to refer to the type of traditional Islamic education typical in Indonesia. Pondok or pesantren, the term 
used in Java Island, including Sundanese and Madura. While in Aceh, known as dayah or rangkang or meunasah, while in West Sumatra is called surau (Dhofier, 1994). Pesantren according to the basic understanding is "a place to learn the students", while the cottage means "a house or a simple place to live made of bamboo". In addition, "cottage" is also derived from the Arabic "funduk" which means "hotel or dormitory". (Nata, A., 2001) there is another term that defines pesantren derived from sansekert language. The origin of the word san means a good person (man) connected tra means to help, santra means a good person who likes to help. Pesantren means a place to educate people to be good people (Nata, 2001).

Another understanding of pesantren is that the word santri comes from Javanese language, cantrik which means people who always follow the teacher where the teacher goes to settle to be able to learn from the teacher about something skill (Madjid, 1997). Another definition of pesantren is, The word pesantren stems from "santri" which means one who seeks Islamic knowledge. Usually the word pesantren refers to a place where the santri devotes most of his or her time to live in and acquire knowledge (Mas'ud, 2002). Pesantren is the oldest Islamic educational institution that is a product of local Wisdom of Indonesia. Pesantren has always been a source of inspiration that never dry for lovers of science and researchers who seek to parse their anatomy from various dimensions. As an educational institution that has long been rooted in this country, we recognize pesantren to have a huge role in the history of the nation. Pesantren not only gave birth to the most influential national figures in the country, but also recognized to have formed its own character, where the Indonesian nation that is majority Muslim has been known as an accommodating and tolerant nation.

Pesantren is a unique educational institution. Not only because of its eternal existence but also because of the culture, methods, and simplicity applied by the religious institution. The simplicity of pesantren used to be very visible, both in terms of physical buildings, methods, study materials and other learning devices. This was because of the condition of society and the economy at that time (Mastuki, 2003). Another sign of this institution is the sincere attitude that the students and teachers have. Their relationship is not just as a student and teacher, but more like a child and a parent. No wonder if students feel like lingering in pesantren even with all its limitations and simplicity (Ismail, 2004). Throughout history, pesantren continued to pursue the field of education and make it as the focus of pesantren activities. In developing education, pesantren has shown a strong enough resilience so that it can pass through various times with various problems faced by it. In its history, pesantren has contributed something significant to Islamic education in the archipelago. (2) Madrasah, Madrasah comes from Arabic. The basic word madrasah means learning. Madrasah is then often interpreted as a place to learn because isim makan (Ali, et.al, 2000). Using madrasas in Indonesian is schools, more Islamic schools. Based on this, we can understand that madrasah is an institution that teaches Islamic sciences. The word madrasah in the Arab country is intended for all schools. In Indonesia, we intend it for schools that study Islamic teachings in more detail (Nasir, 2005).

The process of the birth of madrasah is because of several factors, including the First, the renewal factor in Islam. The birth of madrasah could not be separated from an Islamic renewal movement started by students who had studied in the Middle East. Second, the response to the dutch government's educational politics. The school founded by the Dutch colonial as a political tool of the ruler and its discriminatory nature and managed, making Muslim intellectuals look to reconstruct a more advanced Islamic education. Madrasah has experienced the development of the level and type in line with the development of the 
Indonesian nation (Syar'i, et.al., 2020). These developments have transformed education from basic forms such as studying in houses, mosques, and mosques into formal school institutions, such as madrasas known today. (3) Islamic Higher Education, Islamic higher education also gets attention from the community since its start and get a suitable response from the community in Indonesia. Islamic higher education institutions have contributed to the development of education in Indonesia as part of the national education system. The development of Islamic studies in Islamic universities has also contributed a lot in educating the life of the Indonesian nation. Islamic High School (STI) which was founded in July 1945 is the forerunner of the birth of Islamic universities in Indonesia (Nurdin, 2021). After the proclamation of independence, the capital of the Republic of Indonesia, there was a political upheaval that then required a move to Yogyakarta, then the Islamic High School they moved it to the city of gudeg in 1946. On March 22, 1946, it changed the name of the Islamic High School to Universitas Islam Indonesia with four faculties: education, law, and economics. The Faculty of Religion of the Islamic University of Indonesia (UII) Yogyakarta was transformed into the State Islamic College (PTAIN). At first, the concentration of knowledge in IAIN/STAIN was the development of religious sciences. Addressing globalization with the growing demands and aspirations to integrate science classified as perennial knowledge and science classified as gained knowledge, then came the idea to redevelop IAIN into a university. This idea gave birth to the State Islamic University (UIN).

The next development, the world of Islamic universities in Indonesia, especially IAIN and STAIN, is stretched to continue to adjust to the developments that occur on a local or global scale. His form is to expand the authority that he has had so far, which is then called the "wider mandate" program (expanded mandate) as well as transforming or transforming from IAIN/STAIN to State Islamic University (UIN). It will support the existence of Islamic Universities (UIN, IAIN, STAIN) in the future. The change of IAIN to UIN and stain change to IAIN /UIN is expected to provide opportunities for reconstruction or reintegration of scientific buildings, which bridge the religious and general sciences that have been viewed dichotomically. So that later, graduates of UIN, IAIN, and STAIN can compete with other public universities. In addition, the alumni are people who have knowledge that is useful for themselves and society and has the ability in the field of technology.

So that in the development of alumni of Islamic religious universities are perceived benefits by the community not only in the religious sector but also in other sectors such as science and technology, thus strengthening educational relationships with the community including educational relationships with social change, economic order, politics and the State. Because education occurs in the community, with community resources, and for the community, it required education to take into account and expect the simultaneous social, economic, political and state development. While on a micro scale, education always considers the individuality or characteristics of differences between individual learners in terms of interaction of the learning process.

Education has a role in social change, among which there are two indicators: (1) education will affect the change of society, and (2) education must contribute optimally to the transformation process towards the realization of civil society. Changing the education system must be done with good planning and strategic measures, identifying various problems that hinder the implementation of education and planning reform measures that are more strategic and practical so that they can be implemented in the field, or more operational. It must carry these stages out in a planned, systematic, and touching all sides of life, anticipating changes that occur, able to engineer the formation of intelligent human 
resources, which have innovative capabilities and can improve human quality. Therefore, education will affect the changes in people's lives and can contribute optimally to the process of transformation of science and training that can be implemented in human life.

As part of the national education system, Islamic educational institutions are not only required to hold primary, secondary, and higher education with religious characteristics, but furthermore Islamic educational institutions are also required to play a role as a formidable fortress that will maintain and strengthen the ethics and morals of the nation. In the era of science and technology, religion is relevant to human life. Religion offers values can create social balance and drop all forms of hostility, hatred, violence, and human exploitation. The importance of religion in the $21^{\text {st }}$ century is a force for Islamic educational institutions to further develop. The soul of Islamic educational institutions as a moral bulwark of moral defense of the Indonesian nation is relevant to the vision of national education development, realizing a godly and productive Indonesian people.

Seeing Islamic educational institutions that try to integrate religious sciences and sciences, the Islamic educational institutions, have played the following role: (1) Media Socialization of Religious Teaching Values, Islamic educational institutions have a greater opportunity that serves as a medium of socialization of religious teaching values to students more because it is given early. The religious nature attached to the institution makes Islamic educational institutions have a strong mandate to perform this role (Rahim, 2001). (2) Keeping Religious Traditions, one of the important roles held by Islamic educational institutions is to support religious traditions. The maintenance of religious traditions is conducted besides through the teaching of religious sciences, also done through habituation to practice and practice religious sharia early on. (3) Establishing Morality and Personality, The purpose of education in Islamic educational institutions is not only to enrich the minds of learners with knowledge, but to elevate morals, train and elevate morale, respect spiritual and humanitarian values, teach honest and moral attitudes and behaviors, and prepare learners to live simple and clean-hearted lives. (4) Alternative Education Institutions, Concentration of development focused on materials today have given birth to a lame life. On the one hand, it is exaggerated in terms of matter, but it feels mentally empty spiritually. This is where Islamic educational institutions become alternative education, which is the balance between general knowledge and religion. (5) The Fortress of Morality of the Nation, The phenomenon of the development of murder, sadistic robbery, increasing juvenile delinquency, the development of free association and the practice of prostitution, the deterioration of social care of the community, causing the public to see and rethink to Islamic educational institutions such as madrasas, Islamic boarding schools and universities to deliver and deliver their children to study in Islamic educational institutions, because they are worried about the uncontrollable conditions of the times. Plus, the smartphone phenomenon today that all children have it and are free to use it with no supervision from parents.

One of the Islamic educational institutions that take a role in the social change of the community, the people in the Gayo plateau is the Takengon State Islamic Institute, which is the only State Islamic religious college in the Gayo plateau covering the central Aceh region, Bener Meriah and Gayo Lues. Of course, Islamic educational institutions is strongly felt by the Gayo community, now that the world is during a corona outbreak (covid-19), which hit all sides of human life, ranging from religious, socioeconomic, political and cultural practices.

Based on observations, interviews and documentation, the State Islamic Institute of Takengon, does not stay silent in the face of covid-19, but takes progressive measures, in education that is indeed a higher education institution certainly has a big part in advancing 
education in the Gayo plateau. This is realized by taking active steps, regarding educational activities, research and community service by lecturers who teach at the Takengon State Islamic Institute. Of course, the standards used during the covid-19 period are under the circular of the minister of national education. Education is carried out in the process of distance education or also called online (online) so that students survive despite experiencing covid-19, so it is expected that when they return to the community can be an agent of change for social change of society for the better. Lecturers and students carried research out as the means to know various problems that occur in the community, review problems and find solutions to them. Community service, also carried out by lecturers and students as contribution of educational institutions to the community through lectures or counseling conducted in order to educate the public to maintain strict health protocols such as maintaining distance, washing hands and wearing masks in daily activities.

\section{Conclusion}

The contribution of Islamic educational institutions to the change in the social life of the Gayo plateau community during the covid-19 period is realized as implementing the Tri Dharma of Higher Education, including Education, Research and Community Service. Education is carried out in the process of distance education or also called online (online) so that students survive despite experiencing covid-19, so it is expected that when they return to the community can be an agent of change for social change of society for the better. Lecturers and students carries research out as one means to know various problems that occur in the community, review problems and find solutions to them. Community service, also carried out by lecturers and students as contribution of educational institutions to the community through lectures or counseling conducted in order to educate the public to maintain strict health protocols such as, maintaining.

This research provides information related to the contribution of Islamic educational institutions in the framework of character development among the Gayo community during the Covid-19 pandemic. An important contribution of this study, first, based on observations of social symptoms and phenomena occurring in the Gayo Highlands public, there is a change in the socio of society because of Covid-19. Second, academic institutions in Gayo such as the Takengon State Islamic Religious Institute contributes, directly and indirectly, to help the society cope with the impact of Covid-19 changes. Third, apply the point of view of education by still conducting distance teaching to undergraduates to survive despite facing Covid-19. Lecturers and students too conducted explore to find out various problems in the people during the pandemic and find solutions. Fourth, a research on the contribution of Islamic educational institutions to the transitions in the civil behavior of the Gayo society during the covid-19 time.

The issues of society life with the new norms facing the impact of Covid-19 will yet last a long time. As an assist to the solution, we recommend that educational institutions in Gayo in specific and Indonesia advance to aid the district through humanitarian environment by conducting studies that affect the community.

This review has two limitations. First, this study is an observation of societal changes and the contribution of Islamic Educational institutions during the Covid-19 pandemic. This requires a more comprehensive policy study of the impact faced by the Gayo community. However, this requires large funds to find out the problems faced by the Gayo community during the Covid19 pandemic. Thus, it is important to plan some policies, rules, and principles related to the 
provision of help that further meets the needs of the community to be provided by individuals or countries. Second, we could not examine the impact of the Covid-19 pandemic on the finances and economics of the Gayo community as one that affected community socio-change because of the absence of data.

\section{Acknowledgments}

This research was funded by the Research Fund TIER 1 H825, Research Management Centre, University Tun Hussein Onn Malaysia.

\section{References}

Muhdlor, A. A., \& Zuhdi, A. (2010). Kamus Al-'Ashri Arab-Indonesia. Yogyakarta: Ma'had Krapyak

Benn, T., Dagkas, S., \& Jawad, H. (2011). Embodied faith: Islam, religious freedom and educational practices in physical education. Sport, education and society, 16(1), 17-34.

Bogmatsera, E., Savtsova, N., \& Kurbanov, A. (2019). The impact of terrorism as a social phenomenon on the political and religious spheres of the society. Revista Inclusiones, 181-192.

Dhofier, Z. (1990). Tradisi pesantren: Studi atas pandangan hidup kyai. Jakarta: LP3ES.

Ismail, F. B. H., Kirin, A., Masruri, M., \& Marpuah, S. (2020). The Impact of Covid-19 Pandemic to Worship. International Journal of Academic Research in Business and Social Sciences. 10(11), 256-270.

Ismail, F. (2004). Paradigma Kebudayaan Islam: Studi Kritis dan Analisa Historis, cet. Ke-4. Jakarta: PT. Mitra Cendekia.

Maarif, A. S. (1991). Pendidikan Islam di Indonesia. Tiara Wacana Yogya.

Madjid, N. (1997). Bilik-bilik pesantren: sebuah potret perjalanan. Paramadina.

Mas'ud, A. (2002). Sejarah dan Budaya Pesantren, dalam Ismail SM, et. al. Dinamika Pesantren dan Madrasah, Yogyakarta: IAIN Walisongo Semarang dan Pustaka Pelajar.

Mastuhu. (1999). Perdayakan system pendidikan islam, Jakarta: logos.

Mastuki. (2003). Intelektualisme Pesantren: Potret Tokoh dan Cakrawala Pemikiran di Era Perkembangan Pesantren, Jakarta: Diva Pustaka

Nasir, M. R. (2005). Mencari Tipologi Format Pendidikan Ideal: Pondok Pesantren di Tengah Arus Perubahan. Pustaka pelajar.

Nata, A. (2001). Sejarah Pertumbuhan dan Perkembangan Lembaga-Lembaga Islam di Indonesia. Jakarta: Gramedia Widiasarana Indonesia.

Nurdin, A. (2021). Modernization of Islamic Higher Education in Indonesia at A Glance: Barriers and Opportunities. International Journal of Multicultural and Multireligious Understanding, 8(3), 288-296.

Sanaky, H. A. (2003). Paradigma Pendidikan Islam: Membangun Masyarakat Madani Indonesia. MSI, Universitas Islam Indonesia.

Syar'i, A., Hamdanah, H., \& Akrim, A. (2020). The Development of Madrasa Education in Indonesia. Revista Argentina de Clínica Psicológica, 29(4), 513-523.

Yin, R. K. (1994). Case study research: Design and methods, applied social research. Methods series, 5. Thousand Oaks, London, New Delhi: Sage Publication. 